\title{
Performance of the Visual Analogue Scale of Happiness and of the Cornell Scale for Depression in Dementia in the Tremembé Epidemiological Study, Brazil
}

\author{
Karolina G. César ${ }^{1,2}$, Sonia M.D. Brucki ${ }^{1}$, Leonel T. Takada³, Luiz Fernando C. Nascimento², \\ Camila M.S. Gomes ${ }^{3}$, Milena C.S. Almeida³, Maira O. Oliveira33, Fábio H.G. Porto³, Mirna L.H. Senaha3 \\ Valéria S. Bahia ${ }^{3}$, Thaís Bento L. Silva ${ }^{3}$, Jéssica N. lanof ${ }^{3}$, Lívia Spíndola ${ }^{3}$, Magali T. Schmidt ${ }^{3}$, \\ Mário S. Jorge ${ }^{3}$, Patrícia H.F. Vale ${ }^{3}$, Mário A. Cecchini ${ }^{3}$, Luciana Cassimiro ${ }^{3}$, Roger T. Soares ${ }^{3}$, \\ Márcia R. Gonçalves ${ }^{3}$, Jerusa Smid ${ }^{3}$, Claudia S. Porto ${ }^{3}$, Maria Teresa Carthery-Goulart ${ }^{3}$, \\ Mônica S. Yassuda ${ }^{3}$, Letícia L. Mansur ${ }^{3}$, Ricardo Nitrini ${ }^{4}$
}

\begin{abstract}
Depression is a major growing public health problem. Many population studies have found a significant relationship between depression and the presence of cognitive disorders. Objective: To establish the correlation between the Visual Analogue Scale of Happiness and the Cornell Scale for Depression in Dementia in the population aged 60 years or over in the city of Tremembé, state of São Paulo, Brazil. Methods: An epidemiological survey involving home visits was carried out in the city of Tremembé. The sample was randomly selected by drawing 20\% of the population aged 60 years or older from each of the city's census sectors. In this single-phase study, the assessment included clinical history, physical and neurological examination, cognitive evaluation, and application of both the Cornell Scale and the Analogue Scale of Happiness for psychiatric symptoms. The presence of depressive symptoms was defined as scores greater than or equal to 8 points on the Cornell Scale. Results: A total of 623 subjects were evaluated and of these 251 (40.3\%) had clinically significant depressive symptoms on the Cornell Scale, with a significant association with female gender $(p<0.001)$ and with lower education $(\mathrm{p}=0.012)$. One hundred and thirty-six participants $(21.8 \%)$ chose the unhappiness faces, with a significant association with age $(p<0.001)$, female gender $(p=0.020)$ and low socioeconomic status $(p=0.012)$. Although there was a statistically significant association on the correlation test, the correlation was not high (rho $=0.47$ ). Conclusion: The prevalence of depressive symptoms was high in this sample and the Visual Analogue Scale of Happiness and Cornell Scale for Depression in Dementia should not be used as similar alternatives for evaluating the presence of depressive symptoms, at least in populations with low educational level.
\end{abstract}

Key words: depression, elderly, prevalence, Cornell Scale for Depression, Visual Analogue Scale of Happiness.

\section{DESEMPENHO NA ESCALA ANALÓGICA VISUAL DE FELICIDADE E NA ESCALA CORNELL DE DEPRESSÃO EM DEMÊNCIA NO ESTUDO EPIDEMIOLÓGICO DE TREMEMBÉ, BRASIL}

RESUMO. A depressão é um problema importante e crescente de saúde pública. É muito comum ser encontrada uma relação significativa entre depressão e a presença de distúrbios cognitivos nos estudos populacionais. Objetivo: Estabelecer a correlação entre a Escala Analógica Visual de Felicidade e a Escala Cornell de Depressão em Demência na população de 60 anos ou mais da cidade de Tremembé, estado de São Paulo, Brasil. Métodos: Estudo epidemiológico no qual foram realizadas visitas domiciliares na cidade de Tremembé. A amostra foi aleatória, através do sorteio de $20 \%$ da população acima de 60 anos de cada setor censitário do município. Este estudo foi de fase única, tendo sido realizada anamnese, exames físico e neurológico, avaliação cognitiva e aplicação de escalas Cornell de Depressão em Demência e Escala Analógica de Felicidade para verificar a presença de sintomas depressivos. Foi adotado como critério da presença de sintomas depressivos, pontuação maior ou igual a 8 na escala de Cornell. Resultados: Foram avaliadas 623 pessoas e destas 251 (40,3\%) apresentaram sintomas depressivos significativos clinicamente na escala de Cornell, com associação significativa com

\footnotetext{
${ }^{1} \mathrm{MD}$, PhD. Cognitive and Behavioral Neurology Unit, Department of Neurology, University of São Paulo, Brazil; ${ }^{2}$ Professor at the University of Taubaté, Brazil; ${ }^{3}$ Tremembé Epidemiologic Study (TES) Group; ${ }^{4} \mathrm{MD}$, PhD, Full Professor. Professor of Neurology, University of São Paulo Medical School. Cognitive and Behavioral Neurology Unit, Department of Neurology, University of São Paulo, Brazil.
}

Karolina G. César. Av. Armando Salles de Oliveira 200 - 12030-080 Taubaté SP - Brazil. E-mail: karolgcesar@gmail.com

Disclosure: The authors report no conflicts of interest.

Received December 10, 2013. Accepted in final form April 17, 2014. 
gênero feminino $(p<0,001)$ e com a baixa escolaridade $(p=0,012)$. Cento e trinta e seis participantes $(21,8 \%)$ apontaram para faces de infelicidade, com associação significativa com idade $(p<0,001)$, com gênero feminino $(p=0,020)$ e com baixo nível socioeconômico ( $p=0,012)$. Embora tenha havido significância estatística no teste de correlação, a correlação entre as duas escalas analisadas não foi alta (rho=0,47). Conclusão: A prevalência de sintomas depressivos foi elevada nesta amostra e a Escala Analógica de Felicidade e a Escala Cornell de Depressão em Demência não devem ser utilizadas como alternativas similares para avaliar a presença de sintomas depressivos, pelo menos em populações com baixa escolaridade. Palavras-chave: depressão, idosos, prevalência, Escala de Cornell, Escala Analógica Visual de Felicidade.

\section{INTRODUCTION}

Depression is a major and growing public health problem and possibly the leading cause of mental disability. ${ }^{1}$ It is very common in the elderly population and many population studies have found a significant relationship between depression or depressive symptoms and the presence of cognitive disorders..$^{2-4}$

Several instruments can be used to detect and measure level of depression, two of which stand out for their practical application: the Cornell Scale ${ }^{5}$ and the Visual Analogue Scale of Happiness (VASH). ${ }^{6}$ The Cornell Scale, despite having been initially developed for the diagnosis and monitoring of depression in patients with dementia, is also a validated instrument for use in both demented and non-demented geriatric subjects. ${ }^{7}$ It is also slightly more comprehensive than the geriatric depression scale, ${ }^{8,9}$ by covering issues related to anxiety, behavioral and sleep changes. The VASH contains six faces expressing from great happiness to deep sadness or unhappiness, and the participant need only indicate which face best identifies their mood. ${ }^{6}$

The aim of this study was to establish the correlation between the VASH and the Cornell Depression Scale in an epidemiological study conducted to diagnose cognitive disorders in the population aged 60 years or over in the city of Tremembé, state of São Paulo, Brazil.

\section{METHODS}

This study was an epidemiological study in which home visits were carried out in the city of Tremembé, located in the State of São Paulo, about $140 \mathrm{~km}$ from the State capital. According to the population census conducted in 2011 by the Brazilian Institute of Geography and Statistics (IBGE), Tremembé had a population of 40,751 inhabitants, of whom 3,690 were aged 60 years or more (185 of whom lived in rural areas). ${ }^{10}$ This study was approved by the University of São Paulo Research Ethics Committee (protocol 0378/09).

Sampling. The initial parameters of the sample were estimated for a study on the prevalence of cognitive impairment with and without dementia, which was the primary objective of this study. ${ }^{6}$ Twenty percent of the households with individuals aged 60 years or over were randomly selected from each of the municipality's census sectors to obtain a homogeneous representation of all regions and districts as well as different socioeconomic levels. Seven hundred and thirty-eight individuals aged 60 years or more were randomly selected from both urban and rural areas.

Following selection, letters were sent by mail inviting subjects to participate in the study. Subsequently, a community agent visited the homes and scheduled a home visit. The subjects or legal guardians were fully informed about the study and signed a consent form. Only one individual was included from each selected household. Individuals institutionalized in either of the city's nursing homes were included in the study following randomization, but only individuals who were randomly selected in their respective census sector were examined at these institutions.

Exclusion criteria. The study excluded only those who did not have informants to help answer the questionnaires. When the elderly drawn refused to participate, we invited the nearest neighbor aged 60 years or more to participate, to minimize sample loss and try to maintain the percentage of subjects sampled from each sector. The three city's prisons sectors were excluded from the study and another nine sectors were also excluded because they contained no residents aged 60 years or over.

Assessment. A cross-sectional survey was conducted in which history taking, physical and neurological examination, cognitive assessment, psychiatric evaluation and functional activity questionnaires were carried out in a single-phase visit. ${ }^{11}$

Two previously cited scales were employed for the evaluation of psychiatric symptoms: the Cornell Depression Scale ${ }^{5,12}$ and the Patient Health Questionnaire (PHQ) from the Primary Care Evaluation of Mental Disorders (PRIME-MD) which included the VASH. ${ }^{6,13}$

The diagnostic criterion adopted for clinically significant depressive symptoms was a score greater than or equal to 8 points on the Cornell scale. ${ }^{7}$ For the VASH, subjects that chose the faces Little Unhappy, Unhappy 
or Very Unhappy were considered as presenting depressive symptoms.

Statistical analysis. Statistical analyses were performed using the SPSS (Statistical Package for the Social Sciences) version 17.0 software. The degree of association between the Cornell Scale and the Visual Analogue Scale of Happiness, and age, level of education, gender and socioeconomic status, was determined by Pearson's Chi-square test between crossed variables. The degree of correlation between the two scales was determined by Spearman's test and the evaluation of agreement between both scales by McNemar's test.

\section{RESULTS}

Twenty percent of the population over 60 years of age was randomly selected, which corresponded to 738 households. Of these, 630 subjects agreed to participate although seven were in advanced stages of dementia and could not answer the Cornell Scale and VASH. This gave a final study sample of 623 participants.

Two hundred and fifty-one participants (40.3\%) who answered the Cornell scale were diagnosed with clinically significant depressive symptoms (Cornell $\geq 8$ points). One hundred and thirty-six participants (21.8\%) chose a face with some degree of unhappiness on the VASH (Table 1).

There was a significant difference between the two scales $(\mathrm{p}<0.001)$ (Table 1 ) where Spearman's correlation coefficient was low (0.47) and then showed disagreement. Therefore, these two scales do not measure exactly the same variable. Analysis of agreement between diagnoses obtained using both scales (McNemar's test) showed the same significant disagreement $(\mathrm{p}<0.001)$. Thus, a high score found on the Cornell scale did not necessarily coincide with an unhappy face on Visual Analogue Scale of Happiness, as shown in Figure 1.
Regarding the Cornell scale, female gender $(\mathrm{p}<0.001)$ as well as lower education ( $\mathrm{p}=0.012)$ showed a significant correlation with the presence of the diagnosis of clinically significant depressive symptoms (Table 2). The association with socioeconomic level almost reached significance $(\mathrm{p}=0.053)$.

In relation to the VASH, there was no significant association of education with unhappy mood but there was an association with age $(\mathrm{p}<0.001)$, female gender $(\mathrm{p}=0.020)$ and low socioeconomic status $(\mathrm{p}=0.007)$ (Table 3) was detected.

\section{DISCUSSION}

Depression appears in some studies as another risk factor for the onset of cognitive impairment, but it could be a prodrome or even be a possible cause of reversible dementia. ${ }^{14}$ The management of depressive symptoms

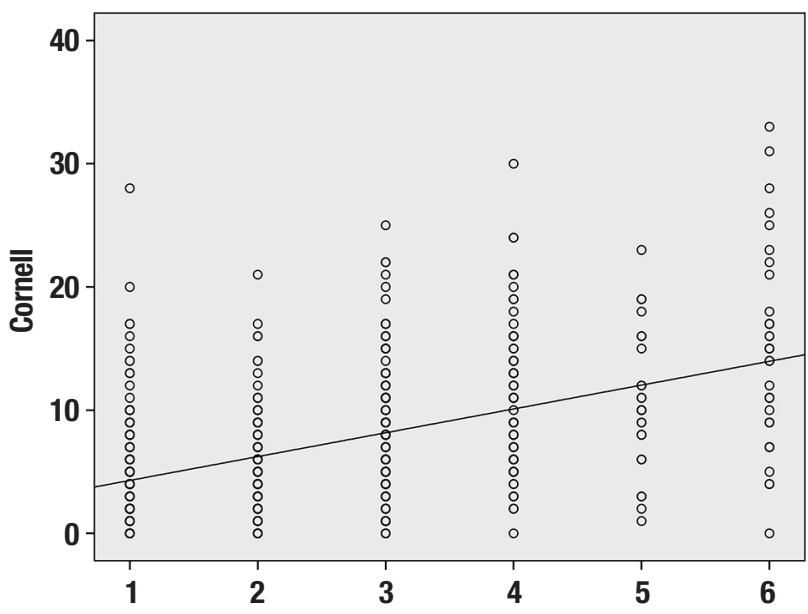

Spearman $=0.47$; Visual Analogue Scale of Happiness: 1=Very Happy; 2=Happy; 3=Neutral; 4=Little Unhappy; 5=Unhappy; 6=Very Unhappy.

Figure 1. Correlation between scores on the Cornell scale and on the Visual Analogue Scale of Happiness scale.

Table 1. Association between no. of depression cases detected on the Cornell scale and on the Visual Analogue Scale of Happiness.

\begin{tabular}{|c|c|c|c|c|c|}
\hline & & \multicolumn{2}{|c|}{ Cornell } & \multirow[b]{2}{*}{ Total } & \multirow[b]{2}{*}{ p Value } \\
\hline & & Without depression & With depression & & \\
\hline \multirow[t]{6}{*}{ V.A.S.H. } & Very happy & 133 & 35 & 168 & $<0.001$ \\
\hline & Happy & 119 & 31 & 150 & \\
\hline & Neutral & 82 & 87 & 169 & \\
\hline & Little Unhappy & 25 & 51 & 76 & \\
\hline & Unhappy & 6 & 19 & 25 & \\
\hline & Very unhappy & 7 & 28 & 35 & \\
\hline Total & & 372 & 251 & 623 & \\
\hline
\end{tabular}

V.A.S.H.: Visual Analogue Scale of Happiness; *' Spearman's Correlation; without depression $<8$ and with depression $\geq 8$ points on the Cornell Scale. 
Table 2. Cornell scale by age, gender, education and socioeconomic level.

\begin{tabular}{|c|c|c|c|c|c|}
\hline \multirow[b]{3}{*}{ Variables } & & \multicolumn{4}{|c|}{ Cornell Scale } \\
\hline & & Without depression (\%) & With depression (\%) & & Total (\%) \\
\hline & & $N=372$ & $\mathrm{~N}=251$ & p Value* & $\mathrm{N}=623$ \\
\hline \multirow[t]{7}{*}{ Age groups } & & & & 0.176 & \\
\hline & $60-64$ years & $82(22.0)$ & $70(27.9)$ & & $152(24.4)$ \\
\hline & $65-69$ years & $93(25.0)$ & $50(23.5)$ & & $152(24.4)$ \\
\hline & $70-74$ years & $75(20.2)$ & $41(16.3)$ & & $116(18.6)$ \\
\hline & $75-79$ years & $64(17.2)$ & $34(13.5)$ & & $98(15.7)$ \\
\hline & 80-84 years & $36(9.7)$ & $26(10.4)$ & & $62(10.0)$ \\
\hline & $\geq 85$ years & $22(5.9)$ & $21(8.4)$ & & $43(6.9)$ \\
\hline \multirow[t]{3}{*}{ Gender } & & & & $<0.001$ & \\
\hline & Male & $166(44.6)$ & $63(25.1)$ & & $229(36.8)$ \\
\hline & Female & $206(55.4)$ & $188(74.9)$ & & 394 (63.2) \\
\hline \multirow[t]{6}{*}{ Years of education } & & & & 0.012 & \\
\hline & Illiterate & $44(11.8)$ & $42(16.7)$ & & $86(13.8)$ \\
\hline & $1-4$ years & $200(53.8)$ & $143(57.0)$ & & $343(55.1)$ \\
\hline & $5-8$ years & $46(12.4)$ & $37(14.7)$ & & 83 (13.3) \\
\hline & $9-11$ years & $36(9.7)$ & $14(5.6)$ & & $50(8.0)$ \\
\hline & $\geq 12$ years & $46(12.4)$ & $15(24.6)$ & & $61(9.8)$ \\
\hline \multirow[t]{6}{*}{ Socioeconomic level $^{\star \star}$} & & & & 0.053 & \\
\hline & A & $21(5.7)$ & $4(1.6)$ & & $25(4.0)$ \\
\hline & B & $118(31.7)$ & $22(8.8)$ & & $182(29.1)$ \\
\hline & C & $178(47.9)$ & $134(53.4)$ & & $312(50.1)$ \\
\hline & D & 55 (14.8) & 48 (19.1) & & 103 (16.6) \\
\hline & E & $0(0.0)$ & $1(0.4)$ & & $1(0.2)$ \\
\hline
\end{tabular}

*Pearson's $\chi^{2}$ test. ${ }^{*} \mathrm{ABIPEME}$ B Brazilian Association of Market Research (ranging from A [highest] to $\mathrm{E}$ [lowest]). Without depression $<8$, and with depression $\geq 8$ points, on the Cornell Scale.

is crucial in outpatient care of elderly since depression is a predictor of decline in functional abilities.

In previous reported studies, the combined prevalence of significant depressive symptoms and major depressive disorder in elderly Brazilians was $7 \%$ in São Paulo ${ }^{15}$ and depression in the general population was $16.1 \%$ in Porto Alegre. ${ }^{16}$ In the present study, we found a prevalence of $40.3 \%$ of clinically significant depressive symptoms using the Cornell Scale for Depression in Dementia, while the prevalence of unhappiness was $21.8 \%$ when the VASH was employed.

Our data are insufficient to evaluate which of these two scales is most appropriate to detect depressive symptoms in population studies. However, the prevalence obtained with the VASH, where $21.8 \%$ of participants chose the face with some degree of unhappiness, was closer to the previously reported prevalence of depression among the elderly in Brazil. ${ }^{14-16}$ In the SABE study (Health, well-being and aging), the prevalence of depression in the city of São Paulo was $18.1 \%$ when the Geriatric Depression scale was used. ${ }^{17}$
The VASH is easier and much faster to use than the Cornell Scale questionnaire. The Cornell Scale detected depressive symptoms in $40.3 \%$ of the sample while the VASH showed depressive symptoms in $21.8 \%$, a figure which may be closer to the actual rate of depression in the elderly of our community. However, this theory needs to be further tested.

In conclusion, the VASH and the Cornell Scale for Depression in Dementia should not be used as similar alternatives to evaluate the presence of depressive symptoms, at least in populations with low educational level. Further studies are needed to evaluate whether the VASH may be used in epidemiologic studies for the detection of depressive symptoms in poorly educated populations.

Support. The study was supported by FAPESP grant number 2012/04815-6

The study was conducted in the city of Tremembé, state of São Paulo, Brazil by the Department of Neurology, University of São Paulo Medical School 
Table 3. Visual Analogue Scale of Happiness by age, gender, education and socioeconomic level.

\begin{tabular}{|c|c|c|c|c|c|c|c|c|c|}
\hline \multirow[b]{2}{*}{ Variables } & & \multicolumn{8}{|c|}{ Visual Analogue Scale of Happiness } \\
\hline & & $\begin{array}{c}\text { Very } \\
\text { Happy (\%) } \\
\text { N=168 }\end{array}$ & $\begin{array}{c}\text { Happy } \\
\text { (\%) } \\
\mathrm{N}=150\end{array}$ & $\begin{array}{c}\text { Neutral } \\
(\%) \\
N=169\end{array}$ & $\begin{array}{c}\text { Little } \\
\text { Unhappy (\%) } \\
\text { N=76 }\end{array}$ & $\begin{array}{c}\text { Unhappy } \\
\text { (\%) } \\
\mathrm{N}=25\end{array}$ & $\begin{array}{c}\text { Very } \\
\text { Unhappy (\%) } \\
\mathrm{N}=35\end{array}$ & p Value* & $\begin{array}{c}\text { Total } \\
(\%) \\
N=623\end{array}$ \\
\hline \multirow[t]{7}{*}{ Age groups } & & & & & & & & $<0.001$ & \\
\hline & $60-64$ years & $37(22.0)$ & $29(19.3)$ & $49(29.0)$ & $21(27.6)$ & $10(40.0)$ & $6(17.1)$ & & $152(24.4)$ \\
\hline & $65-69$ years & $43(25.6)$ & $43(28.7)$ & $37(21.9)$ & $18(23.7)$ & $3(12.0)$ & $8(22.9)$ & & $152(24.4)$ \\
\hline & $70-74$ years & $20(11.9)$ & $40(26.7)$ & $33(19.5)$ & $13(17.1)$ & $3(12.0)$ & $7(20.0)$ & & $116(18.6)$ \\
\hline & $75-79$ years & $40(23.8)$ & $18(12.0)$ & $18(10.7)$ & $10(13.2)$ & $4(16.0)$ & $8(22.9)$ & & $98(15.7)$ \\
\hline & $80-84$ years & $20(11.9)$ & $14(9.3)$ & $18(10.7)$ & $3(3.9)$ & $3(12.0)$ & $4(11.4)$ & & $62(10.0)$ \\
\hline & $\geq 85$ years & $8(4.8)$ & $6(4.0)$ & $14(8.3)$ & $11(14.4)$ & $2(8.0)$ & $2(5.7)$ & & $43(6.9)$ \\
\hline \multirow[t]{3}{*}{ Gender } & & & & & & & & 0.020 & \\
\hline & Male & $58(34.5)$ & $66(44.0)$ & 67 (39.6) & 23 (30.3) & $10(40.0)$ & $5(14.3)$ & & 229 (36.8) \\
\hline & Female & $110(65.5)$ & $84(56.0)$ & $102(60.4)$ & $53(69.7)$ & $15(60.0)$ & $30(85.7)$ & & 394 (63.2) \\
\hline \multirow{6}{*}{$\begin{array}{l}\text { Years of } \\
\text { education }\end{array}$} & & & & & & & & 0.116 & \\
\hline & Illiterate & 24 (14.3) & $14(9.3)$ & 23 (13.6) & 14 (18.4) & $4(16.0)$ & $7(20.0)$ & & 86 (13.8) \\
\hline & 1-4 years & 95 (56.5) & $82(54.7)$ & 83 (49.1) & 45 (59.2) & $17(68.0)$ & $21(60.0)$ & & $343(55.1)$ \\
\hline & 5-8 years & 21 (12.5) & $16(10.7)$ & 27 (16.0) & $12(15.8)$ & $2(8.0)$ & $5(14.3)$ & & $83(13.3)$ \\
\hline & 9-11 years & $10(6.0)$ & $17(11.3)$ & $16(9.5)$ & $4(5.3)$ & $1(4.0)$ & $2(5.7)$ & & $50(8.0)$ \\
\hline & $\geq 12$ years & 18 (10.7) & $21(14.0)$ & 20 (11.8) & $1(1.3)$ & $1(4.0)$ & $0(0.0)$ & & $61(9.8)$ \\
\hline \multirow{6}{*}{$\begin{array}{l}\text { Socioeconomic } \\
\text { level }^{\star \star}\end{array}$} & & & & & & & & 0.007 & \\
\hline & $A$ & $4(2.4)$ & $11(7.4)$ & $10(5.9)$ & $0(0.0)$ & $0(0.0)$ & $0(0.0)$ & & $25(4.0)$ \\
\hline & $\mathrm{B}$ & 59 (35.1) & $50(33.4)$ & $50(29.6)$ & $17(22.4)$ & $3(12.0)$ & $3(8.6)$ & & $182(29.1)$ \\
\hline & $\mathrm{C}$ & $83(49.4)$ & $65(43.3)$ & 78 (46.2) & 46 (60.5) & $18(72.0)$ & $22(62.8)$ & & $312(50.1)$ \\
\hline & $D$ & $22(13.1)$ & $24(16.0)$ & 31 (18.3) & $13(17.1)$ & $4(16.0)$ & $9(25.7)$ & & $103(16.6)$ \\
\hline & $E$ & $0(0.0)$ & $0(0.0)$ & $0(0.0)$ & $0(0.0)$ & $0(0.0)$ & $1(2.9)$ & & $1(0.2)$ \\
\hline
\end{tabular}

${ }^{\star}$ Pearson's $\chi^{2}$ test. ${ }^{*}$ ABIPEME: Brazilian Association of Market Research (ranging from A [highest] to $E$ [lowest]).

\section{REFERENCES}

1. World Health Organization. Equity, social determinants and public health programmes. Geneva, 2010; World Health Organization.

2. Ortiz GG, Arias-Merino ED, Flores-Saiffe ME, Velázquez-Brizuela IE, Macías-Islas MA, Pacheco-Moisés FP. Prevalence of Cognitive Impairment and Depression among a Population Aged over 60 Years in the Metropolitan Area of Guadalajara, Mexico. Curr Gerontol Geriatr Res 2012;2012:175019.

3. Lopes MA, Hototian SR, Bustamante SEZ, et al. Prevalence of cognitive and functional impairment in a community sample in Ribeirão Preto, Brazil. Int J Geriatr Psychiatry 2007;22:770-776.

4. Juarez-Cedillo T, Sanchez-Arenas R, Sanchez-Garcia S, Garcia-Peña C, Hsiung G-YR, Sepehry AA, et al. Prevalence of mild cognitive impairment and its subtypes in the Mexican population. Dement Geriatr Cogn Disord 2012;34:271-281.

5. Alexopoulos GS, Abrams RC, Young RC, Shamoian CA. Cornell Scale for Depression in Dementia. Biol Psychiatry 1988;23:271-284.

6. Benseñor IM, Pereira AC, Tannuri AC, et al. Systemic arterial hypertension and psychiatric morbidity in the outpatient care setting of a tertiary hospital. Arq Neuropsiquiatr 1998;56:406-411.

7. Alexopoulos GS, Abrams RC, Young RC, Shamoian CA. Use of the Cornell scale in nondemented patients. J Am Geriatr Soc 1988;36: 230-236.

8. Almeida OP, Almeida SA. Reliability of the Brazilian version of the abbreviated form of Geriatric Depression Scale (GDS) short form. Arq Neuropsiquiatr 1999;57:421-426.

9. Sheikh JI, Yesavage JA. Geriatric Depression Scale (GDS): recent evidence and development of a short version. Clin Gerontol 1986;5: 165-173.

10. Instituto Brasileiro de Geografia e Estatística - IBGE. Available from: http://www.ibge.gov.br

11. César KG. Estudo da prevalência de comprometimento cognitivo leve e demência na cidade de Tremembé, estado de São Paulo. [tese]. São Paulo: Faculdade de Medicina, Universidade de São Paulo; 2014.

12. Carthery-Goulart MT, Areza-Fegyveres R, Schultz RR, et al. Versão brasileira da Escala Cornell de depressão em demência (Cornell depression scale in dementia). Arq Neuropsiquiatr 2007;65:912-915.

13. Spitzer RL, Kroenke K, Williams JB. Validation and utility of a self-report version of PRIME-MD: the PHQ primary care study. Primary Care Evaluation of Mental Disorders. Patient Health Questionnaire. JAMA 1999; 282:1737-1744.

14. Ownby RL, Crocco E, Acevedo A, John V, Loewenstein D. Depression and risk for Alzheimer disease: systematic review, meta-analysis, and metaregression analysis. Arch Gen Psychiatry 2006;63:530-538.

15. Barcelos-Ferreira R, Izbicki R, Steffens DC, Bottino CM. Depressive morbidity and gender in community-dwelling Brazilian elderly: systematic review and meta-analysis. Int Psychogeriatr 2010;22:712-726.

16. Cunha RV, Bastos GA, Del Duca GF Prevalence of depression and associated factors in a low income community of Porto Alegre, Rio Grande do Sul. Rev Bras Epidemiol 2012;15:346-354.

17. Lebrão ML, Laurenti R. Saúde, bem-estar e envelhecimento: o estudo SABE no Município de São Paulo. Rev Bras Epidemiol 2005;8: 127-141. 